\title{
Antibody to selected strains of Saccharomyces cerevisiae (baker's and brewer's yeast) and Candida albicans in Crohn's disease
}

\author{
H McKenzie, J Main, C R Pennington, D Parratt
}

\begin{abstract}
IgG serum antibody was measured by ELISA in patients with Crohn's disease (15), ulcerative colitis (15), and in normal controls (15) to 12 strains of Saccharomyces cerevisiae (baker's and brewer's yeast) and to the two major serotypes of the commensal yeast Candida albicans. Antibody to 11 of the 12 strains of $S$ cerevisiae was raised in patients with Crohn's disease but not in patients with ulcerative colitis when compared with controls $(p<0.001)$. The pattern of antibody response to these 11 strains was variable, however, suggesting the likelihood of antigenic heterogeneity within the species. Antibody to C albicans was not significantly different in patient and control groups. The specificity of this unusual antibody response in Crohn's disease for $S$ cerevisiae suggests that it is not simply the result of a generalised increase in intestinal permeability. Furthermore, because brewing and baking strains detected the response, the relevant antigen(s) are presumably common in the diet. Hypersensitivity to dietary antigens may be involved in the pathogenesis of Crohn's disease, and the role of $\boldsymbol{S}$ cerevisiae requires further investigation.
\end{abstract}

We have previously found raised levels of antibody to a strain of baker's yeast (Saccharomyces cerevisiae) in patients with Crohn's disease but not in patients with ulcerative colitis when compared with normal controls.' It is possible that this unusual antibody in Crohn's disease is part of a pathological response to an organism which is involved in the preparation of many components of a typical Western diet. The possibility that hypersensitivity to dietary antigens may contribute to the pathogenesis of Crohn's disease has often been considered and antibody to several food antigens has been studied without providing evidence of a specific abnormality in Crohn's disease..$^{2-5}$

The aim of the present study was to establish whether our initial findings of raised levels of antibody to a single strain of $S$ cerevisiae in Crohn's disease could be extended to other strains of yeast. Although $S$ cerevisiae is the species of yeast used in both brewing and baking, individual strains are specific for each application and may differ in biochemical and antigenic properties. In addition, patients with Crohn's disease are often treated with steroids or broad spectrum antibiotics, and both of these may increase levels of colonisation with the commensal yeast Candida albicans. We therefore measured IgG serum antibody in patients with Crohn's disease or ulcerative colitis and in normal controls to 12 strains of $S$ cerevisiae broadly representative of different industrial applications of this yeast. Antibodies to Candida albicans serotypes $\mathrm{A}$ and $\mathrm{B}$ were also measured in the same patient and control groups.

\section{Methods}

\section{PATIENTS AND CONTROLS}

Blood samples were obtained from patients attending clinics or admitted to hospital with a diagnosis of Crohn's disease (15) or ulcerative colitis (15). In either case, the diagnosis was made by standard clinical, radiological and pathological criteria. Control blood samples (15) were also obtained from volunteer donations to the Blood Transfusion Service. Samples were allowed to clot at room temperature and the serum stored at $-70^{\circ} \mathrm{C}$.

\section{YEAST CULTURES}

Twelve freeze dried strains of $S$ cerevisiae were obtained from the National Collection of Yeast Cultures (NCYC), Norwich. The NCYC strain reference numbers were 77,79 (baking); 87, 431 (distilling); 177, 478 (wine); 240, 1026, 1108 (ale); 1324, 1526, 679 (lager). Two freeze dried strains of $C$ albicans were obtained from the National Collection of Pathogenic Fungi (NCPF), Colindale, London. The NCPF strain reference numbers were 3153 (serotype A) and 3156 (serotype B). All strains were cultured in Sabouraud broth (Oxoid) at $37^{\circ} \mathrm{C}$ for $48 \mathrm{~h}$ and then subcultured on to Sabouraud agar (Oxoid) for $48 \mathrm{~h}$ at $37^{\circ} \mathrm{C}$, before harvesting for antigen preparation. Yeast suspensions in $0.15 \mathrm{M}$ sterile saline were washed and heated at $100^{\circ} \mathrm{C}$ for one hour before adjustment to a standard concentration by measurement of optical density at $540 \mathrm{~nm}$.

\section{ANTIBODY ASSAY}

Yeast antibody was assayed by ELISA as previously described. ${ }^{1}$ Nunclon plates (Gibco) were coated with one strain of yeast per plate and all serum samples tested in duplicate on the same assay plate for each yeast strain. IgG antibody was detected by alkaline phosphatase conjugated affinity purified anti-IgG (Sigma). Assay results were expressed as optical density at $410 \mathrm{~nm}$ after a positive control serum had reached a predetermined value in each assay. 
TABLE Median and range of IgG antibody (optical density) to selected yeast strains in patients with Crohn's disease or ulcerative colitis and in controls

\begin{tabular}{|c|c|c|c|}
\hline & Crohn's disease (15) & Ulcerative colitis (15) & Controls (15) \\
\hline $\begin{array}{l}\text { Candida albicans } \\
\text { NCPF } 3153 \text { serotype A } \\
\text { NCPF } 3156 \text { serotype B }\end{array}$ & $\begin{array}{l}1.07(0.12-1.26) \\
0.50(0.10-0.73)\end{array}$ & $\begin{array}{l}0.80(0.28-1 \cdot 26) \\
0 \cdot 24(0.06-0.59)\end{array}$ & $\begin{array}{l}0.89(0.14-1.26) \\
0.30(0.05-0.64)\end{array}$ \\
\hline $\begin{array}{l}\text { Saccharomyces cerevisiae } \\
\text { Lager strains }\end{array}$ & & & \\
\hline $\begin{array}{l}\text { NCYC } 679 \\
\text { NCYC } 1526 \\
\text { NCYC } 1324\end{array}$ & $\begin{array}{l}0.86(0.06-1 \cdot 51) \\
0.64(0.22-1 \cdot 11)^{\star} \\
0.82(0.09-1.42)^{\star}\end{array}$ & $\begin{array}{l}0.58(0.17-1.45) \\
0.08(0.03-0.94) \\
0.11(0.02-0.77)\end{array}$ & $\begin{array}{l}0.60(0.11-1.43) \\
0.19(0.05-0.61) \\
0.11(0.06-0.68)\end{array}$ \\
\hline $\begin{array}{l}\text { Ale strains } \\
\text { NCYC } 1108 \\
\text { NCYC } 240 \\
\text { NCYC } 1026\end{array}$ & $\begin{array}{l}0.52(0.21-1.44)^{\star} \\
0.64(0.24-1.40)^{\star} \\
0.25(0.05-0.71)^{\star}\end{array}$ & $\begin{array}{l}0.09(0.03-1.00) \\
0.09(0.03-1.00) \\
0.04(0.00-0.60)\end{array}$ & $\begin{array}{l}0.09(0.04-0.59) \\
0.16(0.04-0.59) \\
0.06(0.02-0.18)\end{array}$ \\
\hline $\begin{array}{l}\text { Distilling strains } \\
\text { NCYC } 87 \\
\text { NCYC } 431\end{array}$ & $\begin{array}{l}1.24(0.14-1.99)^{\star} \\
0.41(0.06-0.96)^{\star}\end{array}$ & $\begin{array}{l}0.23(0.06-1 \cdot 70) \\
0.02(0.00-0.67)\end{array}$ & $\begin{array}{l}0.33(0.11-1.44) \\
0.05(0.01-0.43)\end{array}$ \\
\hline $\begin{array}{l}\text { Wine strains } \\
\text { NCYC } 177 \\
\text { NCYC } 478\end{array}$ & $\begin{array}{l}0.37(0.08-0.88)^{\star} \\
0.38(0.04-0.84)^{\star}\end{array}$ & $\begin{array}{l}0.07(0.01-0.47) \\
0.06(0.01-0.38)\end{array}$ & $\begin{array}{l}0.09(0.04-0.44) \\
0.07(0.02-0.55)\end{array}$ \\
\hline $\begin{array}{l}\text { Baking strains } \\
\text { NCYC } 77 \\
\text { NCYC } 79\end{array}$ & $\begin{array}{l}1.20(0.13-1 \cdot 81)^{\star} \\
0.71(0.09-1.51)^{\star}\end{array}$ & $\begin{array}{l}0.05(0.00-1 \cdot 36) \\
0.10(0.01-0.90)\end{array}$ & $\begin{array}{l}0 \cdot 18(0.02-1.01) \\
0 \cdot 12(0.04-0.67)\end{array}$ \\
\hline
\end{tabular}

${ }^{\star} \mathrm{p}<0.001$, significantly different from controls.

STATISTICAL ANALYSIS

The significance of differences between antibody levels in patient and control groups was determined by the Mann-Whitney test. ${ }^{\circ}$

\section{Results}

The results confirmed a significant increase in antibody in patients with Crohn's disease but not in patients with ulcerative colitis when compared with normal controls for 11 of the 12 strains of $S$ cerevisiae tested $(\mathbf{p}<0.001$ for all 11$)$. The exception was a lager strain, NCYC 679, which in common with both serotypes of $C$ albicans, showed no significant difference in antibody between patient and control groups (Table). Antibody results typical of the two different

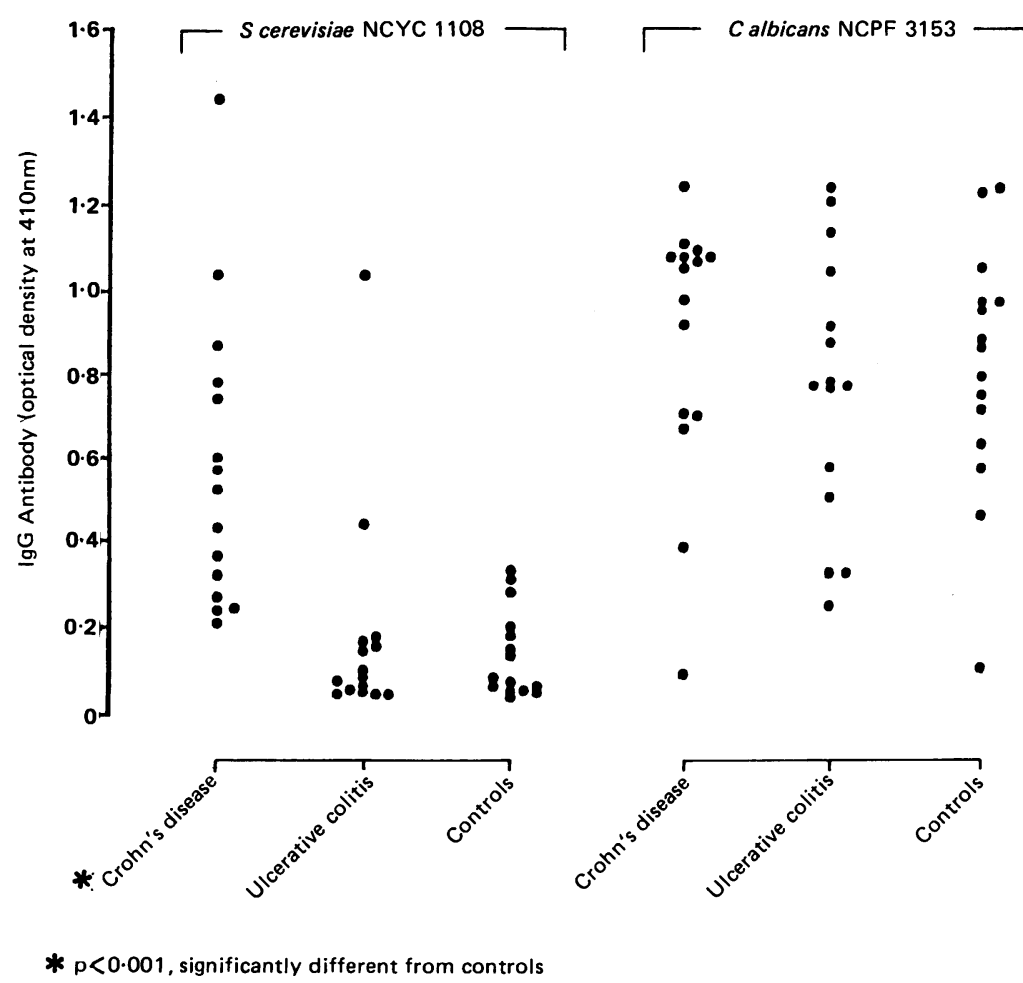

Figure 1: IgG antibody to $\mathrm{S}$ cerevisiae NCYC 1108 and $\mathrm{C}$ albicans NCPF 3153 in patients with Crohn's disease (15) or ulcerative colitis (15) and in controls (15). patterns are shown for $S$ cerevisiae NCYC 1108 and $C$ albicans NCPC 3153 (Fig 1). Although patients with Crohn's disease had raised levels of antibody to all $S$ cerevisiae strains other than NCYC 679, however, the pattern of reactivity of patients to these strains was variable. An example comparison of antibody results for each patient to $S$ cerevisiae ale strain NCYC 1108 and lager strain NCYC 1324 is shown in Figure 2.

\section{Discussion}

Increased antibody levels to dietary antigens in both Crohn's disease and ulcerative colitis have been previously reported and have been attributed to increased absorption of antigens across the inflamed gut mucosa. ${ }^{2-5}$ This study confirms that the abnormal response to $S$ cerevisiae in inflammatory bowel disease is confined to patients with Crohn's disease and also that it is quite distinct from the apparently normal response in such patients to $C$ albicans. C albicans is a commensal yeast which is present in the gastrointestinal tract of approximately $50 \%$ of healthy adults with even higher carriage rates in hospital patients.' Of the candida serotypes used in the present study, serotype A has been reported to account for $74-94 \%$ of clinical isolates, while serotype B accounts for the remainder. ${ }^{7}$ Thus if the raised levels of $S$ cerevisiae antibody in Crohn's disease resulted from increased absorption of antigen caused by the greater permeability of the diseased bowel wall, similar findings would be expected for antibody to $C$ albicans. Our results do not support this, however, and it appears that patients with Crohn's disease respond selectively to $S$ cerevisiae. Patients with ulcerative colitis certainly do not respond to this organism and further studies in other diseases with potentially increased intestinal permeability such as coeliac disease and infective diarrhoea are in progress. Preliminary results tend to suggest that an abnormal antibody response to $S$ cerevisiae is specific for Crohn's disease (unpublished observations).

As baking and brewing strains of $S$ cerevisiae detect the abnormal antibody response, the antigen(s) involved may be common in food and drink. Lager strains of $S$ cerevisiae were once classified separately as Saccharomyces uvarum ${ }^{8}$ and their current status is presently under review. ${ }^{9}$ It is perhaps significant, therefore, that a lager strain of $S$ cerevisiae was the only one to show a different pattern of antigenicity. The variable response of patients with Crohn's disease to the remaining 11 strains of $S$ cerevisiae is also consistent with previous findings of antigenic variability within the species. ${ }^{8}$ It is important to establish whether the raised antibody response to $S$ cerevisiae is directed against multiple antigens, in which case $S$ cerevisiae itself may be important in the pathogenesis of Crohn's disease, or whether the antibody is directed against a single epitope which may be coincidentally shared with the true aetiological agent of the disease. Mannans are thought to form the major antigenic component of yeast cell walls ${ }^{10}$ and are also an important antigenic constituent of mycobacteria. " Mycobacteria have been implicated as 


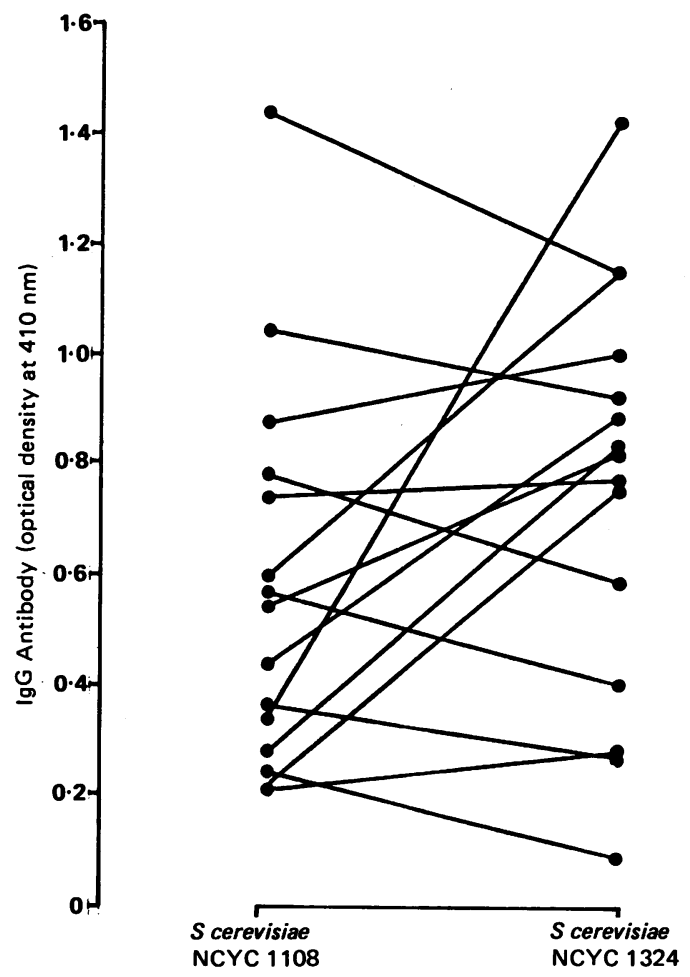

Figure 2: Comparison of IgG antibody to $S$ cerevisiae strains NCYC 1108 and NCYC 1324 in patients with Crohn's disease (15).

the putative infective agents in Crohn's disease, ${ }^{12}$ although the evidence is by no means conclusive. ${ }^{13}$ To resolve these questions, further studies of antigenic heterogeneity among strains of $S$ cerevisiae and of the structure and distribution of the relevant antigens in other microorganisms including mycobacteria are required.

Whether the initial sensitisation is a primary or secondary phenomenon, it is possible that dietary exposure to $S$ cerevisiae antigen(s) results in a hypersensitivity reaction in Crohn's disease. The presence of raised serum antibody to the organism does not prove this, however, and further studies of cell mediated and mucosal immunity are indicated. The histopathological appearance of Crohn's tissue is consistent with cell mediated hypersensitivity, while the extragastrointestinal manifestations of the disease would be in keeping with an immune complex mediated mechanism. Clinical improvement in Crohn's disease following dietary manipulation has been reported, with yeast one of several antigens subjectively identified by patients as causing recurrence of symptoms. ${ }^{14}$ Controlled dietary trials are difficult to perform, however, and the possibility that there are several yeast antigens involved would complicate these. The specificity of the antibody response for $S$ cerevisiae in Crohn's disease increases the likelihood that this is a phenomenon of genuine importance, but much further work will have to be done before the role of the organism in the disease is clear.

This study was supported by the National Association for Coliti and Crohn's disease. We are grateful to Dr K Painting, Nationa Collection of Yeast Cultures, Norwich, for help in the selection of yeast strains, and to Dr G Walker, Dundee Institute of Technology, for helpful discussion.

1 Main J, McKenzie H, Yeaman GR, et al. Antibody to Saccharomyces cerevisiae (baker's yeast) in Crohn's disease. BrMed F 1988; 297: 1105-6.

2 Davidson IW, Lloyd RS, Whorwell PJ, Wright R. Antibodies to maize in patients with Crohn's disease, ulcerative colitis and coeliac disease. Clin Exp Immunol 1979; 35: 147-8.

3 Falchuk KR, Isselbacher KJ. Circulating antibodies to bovine albumin in ulcerative colitis and Crohn's disease. Characterisation of the antibody response. Gastroenterology 1976; 70: 5-8.

4 Paganelli R, Pallone F, Montano S, et al. Isotypic analysis of antibody response to a food antigen in inflammatory bowe disease. Int Arch Allergy Appl Immunol 1985; 78: 81-

5 Knoflach P, Park BH, Cunningham R, Weiser MM, Albini B Serum antibodies to cow's milk in ulcerative colitis and Crohn's disease. Gastroenterology 1987; 92: 479-85.

6 Snedecor GW, Cochran WG. Statistical methods. 6th ed. Iowa: Iowa State University Press, 1967: 131.

7 Odds FC. Candida and candidosis. 2nd ed. London: Baillière Tindall, 1988: 68-92.

8 Fukazawa Y, Shinoda T, Nishikawa A, Nakase T. Synonymy of Saccharomyces cerevisiae Hansen 1883 and Saccharomyces uvarum Beijerinck 1898: Significance of cell wall antigens in uvarum Beijerinck 1898: Significance of cell wall antigens

9 Martini AV, Kurtzman CP. Deoxyribonucleic acid relatednes among species of the genus Saccharomyces sensu stricto. Int $\mathcal{F}$ Syst Bacteriol 1985; 35: 508-11.

10 Reiss E. Molecular immunology of mycotic and actinomycotic infections. New York: Elsevier, 1986: 196-218.

11 Daniel TM, Janicki BW. Mycobacterial antigens: a review of their isolation, chemistry and immunological properties. Microbiol Rev 1978; 42: 84-113.

12 Hampson SJ, McFadden JJ, Hermon-Taylor J. Mycobacteria and Crohn's disease. Gut 1988; 29: 1017-9.

13 Kobayashi K, Brown WR, Brennan PJ, Blaser MJ. Serum antibodies to mycobacterial antigens in active Crohn's disease. Gastroenterology 1988; 94: 1404-11.

14 Alun Jones V, Dickinson RJ, Workman E, Wilson AJ Freeman AH, Hunter JO. Crohn's disease: maintenance of remission by diet. Lancet 1985; ii: 177-80. 